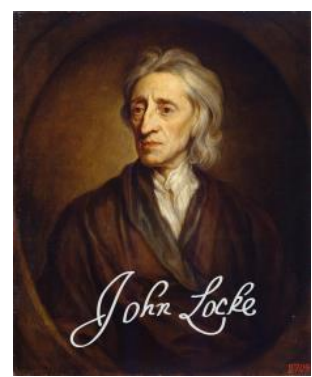

LOCKE STUDIES

Vol. 16

https://doi.org/10.5206/ls.2016.657 | ISSN: 1476-0290

Originally published: 2016

Published online: 10 FEBRUARY 2018

(C) Locke Studies, 2016

\title{
Peter Anstey on Locke's Natural Philosophy
}

\author{
JONATHAN CRAIG WALMSLEY (LONDON)
}

Recommended citation:

Walmsley, Jonathan Craig. "Peter Anstey on Locke's Natural Philosophy." Locke Studies 16 (2016): 167194. https://doi.org/10.5206/ls.2016.657

For more information about this article:

https://ojs.lib.uwo.ca/index.php/locke/article/view/657

Locke Studies is published by The John Locke Society.

This is an open access article published under the terms of the Creative Commons Attribution-

NonCommercial-ShareAlike 4.0 International license, which permits use, distribution and reproduction in any medium, provided the original work is properly cited and shared under the original license. 


\title{
PETER ANSTEY ON LOCKE'S NATURAL PHILOSOPHY
}

\author{
JONATHAN CRAIG WALMSLEY
}

Peter Anstey's book John Locke on Natural Philosophy (Oxford: Oxford University Press, 2011) (henceforth JLNP), presented an interpretation of Locke's work on science and medicine, and how this shaped his philosophical views. It was wide-ranging in scope and often impressively detailed. It raised a number of questions about Locke's relationship to the work of J. B. van Helmont, his collaboration with Thomas Sydenham, and the overall chronology and trajectory of his natural philosophical interests. It also occasioned a number of questions about methodology in the history of philosophy and how we should construct an interpretation of a thinker like Locke from the published, manuscript and historical records available. Some of these questions were posed explicitly in a 'Review Article' in these pages. 1

It is therefore very welcome that Anstey should address some of these questions in some 'Further Reflections on Locke's Medical Remains', first presented as a conference paper, ${ }^{2}$ and now published in this journal. ${ }^{3}$ This paper will address those answers that Anstey chose to provide, as well as some matters he chose to pass over, and conclude with a broader review of Anstey's approach.

\section{\$1. Locke and van Helmont.}

Locke studied medicine at Oxford from the late 1650s up until his

1 J. C. Walmsley, 'Review Article: John Locke and Natural Philosophy', Locke Studies 12 (2012): 243-84.

2 Peter Anstey, 'Citation and Allusion in Locke's Medical Remains', read at the Journée d'étude "Empirisme et méthode dans les manuscripts médicaux de John Locke", ENS de Lyon, 13 November 2014.

${ }^{3}$ Peter Anstey, 'Further Reflections on Locke's Medical Remains', Locke Studies 15 (2015): 215-42. 
departure for London in April 1667, to take up residence in the household of Lord Ashley. Perhaps one of the most interesting points to emerge from a detailed review of Locke's natural philosophical career is how explicitly 'Helmontian' some of this early natural philosophical work appears to be.

Van Helmont was an avowedly 'chymical' thinker who posited a complex ontology to explain natural phenomena. He believed that all matter was derived from water and that 'ferments' impregnated different parts of water with " "seeds" by imposing an 'image' upon it. These seeds arranged matter from the water to match these images and transformed it into various irreducibly chymical elements-i.e. the nature of the elements was not dependent on the shape and size of their particles, but their intrinsic 'chymical' properties. For many chymists the fundamental elements were salt, sulphur and mercury. Helmont also believed that the body contained 'Archei'-quasi-spiritual entities that governed the operation of different organs. In his time at Oxford, Locke read extensively in this tradition (amongst several others), undertook experimental work in 'chymistry' and physiology, and, in two works from 1666-67, 'Morbus' (on the nature of disease), ${ }^{4}$ and 'Respirationis Usus' (on the purpose of respiration), ${ }^{5}$ directly referred to Helmontian ferments and Archei as active agents in nature. Locke's An Essay concerning Human Understanding (London 1690) is generally understood to express an austere mechanism, where impact is the only conceivable corporeal cause because impact is the only instance where we can see a physical cause bringing about its effect. For readers familiar with the mechanism of the Essay, these early non-mechanical views can come as something of a surprise.

${ }^{4}$ British Library (henceforth BL), Add. MS 32554, pp. 232-33, 237, 246, 248-50. Transcribed in J. C. Walmsley, 'Morbus': Locke's Early Essay on Disease', Early Science and Medicine 5 (2000), 366-93, at 390-93.

${ }^{5}$ National Archives (henceforth NA), PRO 30/24/47/2, ff. 71-74. Transcribed and translated in J. C. Walmsley and E. Meyer, 'John Locke's 'Respirationis Usus': Text and Translation', Eighteenth-Century Thought 4 (2008): 1-28. 
But perhaps more surprising is Anstey's assertion that Locke continued to adhere to some form of Helmontianism long after this initial early work in Oxford. This despite significant variations in circumstance, associates, interests, and, as we have noted, what appears to be a clear enunciation of an austere mechanism in the Essay, Locke's most elaborate and polished philosophical work. Indeed, Anstey maintains that Locke was an Helmontian while simultaneously asserting that he rejected 'speculative' hypotheses, and maintained what Anstey calls a 'corpuscular pessimism' - the attitude that it was impossible to know what was going on at the microscopic level and therefore pointless to speculate about it.

This raises a number of interesting questions. First, exactly what sort of Helmontianism does Anstey believe Locke maintained after his time at Oxford? How could it avoid being 'speculative' and positively optimistic about our ability to understand and make strong claims about the corpuscular realm? Second, exactly how long did this adherence to Helmontianism last? And third, what evidence supports these surprising claims? Let us consider these points in turn.

In respect of the first question, to exactly what sort of Helmontianism does Anstey think Locke adhered? Does Anstey believe that Locke believed that all matter was ultimately water? That seeds carrying images imposed themselves on this water to create matter with irreducibly chemical attributes? That the different parts of the body were indeed managed by 'Archei'? Which of these claims, if any, is Anstey making? And how could any of these claims be reconciled with the austere mechanism Locke enunciated in detail in the Essay? In his book, Anstey at one point asserts that Locke adhered to some sort of 'de-vitalised' Helmontianism, ${ }^{6}$ where mechanical explanations were given for 'chymical' phenomena. This, of course, begs the question of how 'Helmontian' such a view would be, since the vitalistic elements are the core of the theory: replace these with mechanism and you merely assert that Locke was an austere mechanist. But in the

\footnotetext{
${ }^{6}$ Anstey, JLNP, 181.
} 
book's conclusion, Anstey throws such caution to the wind, leaves aside any caveats, and asserts that Locke favoured 'various Helmontian conceptions' (without specifying what these were). ${ }^{7}$

In his 'Further Reflections' on the subject, Anstey provides no further answer to this question. He gives no substantive account of which 'Helmontian conceptions' he maintains that Locke believed in - water, seeds, images, ferments, Archei. Without this explanation, it is hard to understand exactly what Anstey thinks Locke believed when he was writing the Essay. This appears to leave a fairly large hole in Anstey's interpretation of Locke's natural philosophy-Anstey does not present a substantive account of Locke's views on the core natural philosophical question of how the world functions in Locke's major philosophical work. Not to mention the fact that the view of material causation presented in the Essay appears to rule out anything other than impact on the primary qualities of bodies as a conceivable mode of physical agency (at least in the early editions, of which more later). It is difficult to subscribe to an interpretation without a clear articulation of what it is supposed to mean. It is more difficult still to subscribe to one that appears to entail something close to a contradiction, where Locke maintains that material causation can only be conceived to be mechanical and yet is simultaneously fundamentally non-mechanical, as Helmont's theory held that it was.

But this appears to be what Anstey asks us to believe. Anstey recognises that some commentators might suppose that Helmontian theory and the austere mechanism Locke articulated in the Essay are not particularly comfortable bedfellows. He imagines such commentators would object that

Locke would not have countenanced explanations in terms of the operations of an archeus once he had committed himself to a corpuscular matter theory and to the efficacy of explanations by analogy with the functioning of machines.

\footnotetext{
${ }^{7}$ Anstey, JLNP, 223.

${ }^{8}$ Anstey, 'Further Reflections', 232.
} 
Anstey takes the point, but does not attempt to reconcile the two theoretical outlooks, tacitly conceding that they are indeed incompatible. Instead he offers some obiter dicta about just how Locke might have been able to entertain these apparently contradictory views:

In my view...in the case of the theory and practice of medicine, Locke had a higher tolerance for cognitive dissonance and we ought to look for Locke's cast of mind, that is, the general characterization of his outlook, rather than to presume that he applied strict principles of logical consistency. $^{9}$

Anstey asks us to suppose that Locke entertained views that he knew to be fundamentally inconsistent, and that he did this for the larger part of his adult life, while composing and publishing what is generally considered to be one of the most important philosophical works of the modern era.

Readers may find it more difficult to suppose that Locke outlined detailed arguments for an austere mechanism over the course of more than a decade, ${ }^{10}$ while simultaneously maintaining that nature worked in entirely extra-mechanical ways. Such a possibility might seem even more unlikely when we recall that, while the Essay contains repeated assertions that corporeal causation can only be conceived to operate by mechanical means, there is not a single instance of Locke referring to any element of Helmontian theory in any of these discussions. Nor does Locke make any reference to Helmontian theory in, for example, his correspondence with Stillingfleet, the drafts of additions to the later editions of the Essay, or in the Elements of Natural Philosophy. ${ }^{11}$

${ }^{9}$ Anstey, 'Further Reflections', 232.

${ }^{10}$ Walmsley, 'The Development of Locke's Mechanism in the Drafts of the Essay', British Journal for the History of Philosophy 11 (2003): 417-49.

11 Though, as J. R. Milton has pointed out ('Locke and the Elements of Natural Philosophy: Some Problems of Attribution', Intellectual History Review 22 (2012): 199-219), some parts of the Elements could not have been written by Locke. The 
Anstey wants us to believe that Locke maintained incompatible theories. Which brings us to the second question raised by Anstey's 'Further Reflections' on this subject-for just how long does Anstey suppose that Locke maintained these inconsistencies? Anstey appears to believe that Locke was an Helmontian for the whole of his adult life-from his time in Oxford to his death in 1704. Anstey starts by noting Locke's references to Helmontian concepts in 'Morbus' and 'Respirationis Usus', citing them as part of the general intellectual climate of the time, and thus concepts that would have remained with him ceteris paribus:

It would only be natural, therefore, that his intellectual trajectory as a physician continued in this track, conceiving of disease and therapeutics in Helmontian terms. This would most likely continue until he encountered strong grounds for changing his basic theoretical orientation. There is no evidence, however, that such a change ever occurred. ${ }^{12}$

This comment is odd, not least because in his book Anstey notes at least three major changes in Locke's basic theoretical orientation after his time at Oxford.

In the first instance, and leaving aside the vexed question of 'influence', Anstey admits that Locke articulated his 'corpuscular pessimism' only after he had left Oxford. ${ }^{13}$ Two papers in Locke's hand written in 1668 and 1669, 'Anatomia' and 'De Arte Medica' state that we will never be able to penetrate into the inner workings of nature, so it is simply pointless to theorise about them-and this same view was further articulated and expanded in the drafts and published editions of the Essay. Locke had never expressed views of this nature previously, and, indeed, his thinking in 'Morbus' and 'Respirationis Usus' assumed that you could make substantive claims about what was happening at the question of how much of the work can be safely attributed to him, and how accurate a view of his thinking it provides, remains open.

${ }^{12}$ Anstey, 'Further Reflections', 234.

${ }^{13}$ Anstey, JLNP, 31-45, and 37 for the date of Locke's first statement of this view. 
unobservable level. It is unclear how this adoption of 'corpuscular scepticism' after Locke left Oxford could count as anything other than a major change in basic theoretical orientation.

The second basic change in theoretical orientation was Locke's adoption of an austere mechanism, ${ }^{14}$ the origin of which Anstey dates to Draft B of the Essay from 1671, ${ }^{15}$ citing accounts of the evolution his views given by Lisa Downing and the present writer. ${ }^{16}$ Locke had never previously articulated the notion that the only corporeal cause we had an idea of was impact, and so that impact was therefore the only conceivable unobservable corporeal cause. This too must count as a change in basic theoretical orientation - perhaps the most important change, since it led directly to Locke's famous distinction between Primary and Secondary Qualities.

The third change in Locke's theoretical outlook is perhaps the most telling in this context. Anstey notes that Newton's work had a significant impact on Locke's views on mechanism. ${ }^{17}$ Regarding corporeal causation, in the first three editions of the Essay, Locke had asserted that:

The next thing to be consider'd, is how Bodies operate one upon another, and that is manifestly by impulse, and nothing else. It being impossible to conceive, that Body should operate on what it does not touch, (which is all one as to imagine it can operate where it is not) or when it does touch, operate any other way than by Motion. ${ }^{18}$

${ }^{14}$ Anstey, JLNP, 19.

${ }^{15}$ Anstey, JLNP, 44.

${ }^{16}$ Anstey, JLNP, 19, n. 31.

${ }^{17}$ Anstey, JLNP, 19, 154.

18 Locke, An Essay concerning Human Understanding, ed. Peter H. Nidditch (Oxford, 1975, corrected reprint 1979). Henceforth Essay. References will cite Book, Chapter and Section number, or page number from this edition), II.viii.11, ed. 1, there are minor changes to eds. 2-3. 
Edward Stillingfleet, Bishop of Worcester, criticised Locke's views of thinking matter, asking how matter could have any form of Liberty (as a thinking thing might), since had Locke asserted that he could only conceive matter to act by impulse. ${ }^{19}$ Locke took this occasion to note that he had changed his view because Newton had demonstrated that there were indeed other ways that bodies could act:

'Tis true, I say, 'that Bodies operate by impulse and nothing else'. And so I thought when I writ it and yet can conceive no other way of their operation. But I am since convinced by the Judicious Mr. Newton's incomparable Book, that 'tis too bold a Presumption to limit God's Power in this Point, by my narrow Conceptions. The gravitation of Matter towards Matter, by ways unconceivable to me, is not only a Demonstration that God can, if he pleases, put into Bodies, Powers, and ways of Operation, above what can be derived from our Idea of Body, or can be explained by what we know of Matter, but also an unquestionable and every where visible Instance, that he has done so. And therefore in the next Edition of my Book, I shall take care to have that Passage rectified. ${ }^{20}$

Locke was as good as his word, reducing the passage in both length and scope in the next edition:

The next thing to be consider'd, is how Bodies produce Ideas in us, and that is manifestly by impulse, the only way which we can conceive Bodies operate in. $^{21}$

It is now only the production of ideas in us that is constrained by conceivability of mechanical interaction, not corporeal causation as a whole. ${ }^{22}$

${ }^{19}$ Edward Stillingfleet, The Bishop of Worcester's Answer to Mr. Locke's Letter (London 1697), 73.

20 John Locke, Mr. Locke's Reply to the Right Reverend the Lord Bishop of Worcester's Answer to his Second Letter (London 1699) (henceforth Second Reply), 408.

${ }^{21}$ Locke, Essay, II.viii.11 (4 ${ }^{\text {th }}$ ed. onwards).

22 Though, as Anstey points out (JLNP 154), Locke was less than thorough in making similar changes elsewhere in the Essay - a failing also reflected in his less than 
All of which raises a question of Anstey's interpretation. If Locke was always committed to the view that there were nonmechanical corporeal causes, why would the appearance of Newton's theory have made any difference to Locke's general outlook? Why would he have thought it necessary to acknowledge that there were non-mechanical causes, and that he would have to change his Essay in recognition of this fact? On Anstey's interpretation, Locke always believed there were nonmechanical causes-Newton's theory would just have been another example of such a theory. Why wouldn't Locke have simply ignored the inconsistency of Newton's theory with the austere mechanism expressed in the Essay, as Anstey apparently believes Locke did with Helmont's? Why didn't Locke simply say something like the following: 'I know I said impulse was the only conceivable corporeal cause, but I didn't really mean itdespite what I appeared to say, I've always thought there were non-mechanical causes because I've always believed in Helmont's theories, and now look! Newton's shown there are other non-mechanical causes. Anyway, there's no need for me to change the Essay, because I've always supposed there was nonmechanical natural agency'?

It would appear that Locke felt the need to acknowledge the impact of Newton on his arguments simply because he would not countenance the 'cognitive dissonance' that Anstey seems comfortable attributing to him. Locke recognised that Newton demonstrated that his assertions about the nature and scope of corporeal causation were inconsistent with the facts of universal gravitation, and adjusted his views accordingly.

Locke, then, seems not to have been all that keen on the type of 'cognitive dissonance' that Anstey ascribes to him. When it came to it he did not want to maintain two inconsistent positions. Whether Locke adjusted his views on this subject fast or far enough is an interesting question, but the fact is that he did adjust

systematic insertion of the phrase 'determined' as a replacement for 'clear and distinct' as outlined in the 'Epistle to the Reader' of the fourth edition of the Essay (Essay, 1314). 
his basic theoretical outlook once again in the light of Newton's work. And he did so in a way which shows that he would not simultaneously assert theories he knew to be mutually inconsistent. Why Anstey believes Locke held the Helmontian theory to a different standard is nowhere explained.

As Anstey himself evidences, Locke's basic theoretical natural philosophical framework did change after he left Oxford, making it more likely that his views on Helmontian theory changed also. Which brings us to the third question raised by Anstey's interpretation - what evidence is there that Locke maintained a life-long commitment to Helmontian theory? As noted above, there can be no doubt whatever that Locke did assent to Helmontian theory during his time at Oxford-'Morbus' and 'Respirationis Usus' clearly adopt elements of that theoretical outlook. Since both pieces are relatively short, and since 'Morbus' in particular takes a reasonably eclectic view, it isn't easy to provide a finally dispositive analysis of Locke's matter theory at this point in his career, but it is clear that Helmont's thinking significantly informed Locke's views. It is equally clear that Locke remained interested in the practice of 'chymistry' long after he left Oxford in 1667-as late as 1689, Locke still included an iron furnace in his luggage. ${ }^{23}$ But the issue here is what evidence there is that Locke subscribed to Helmontian theory, or, indeed, any non-mechanical theory of natural agency, from 1667 onwards? What evidence is there to support the view that Locke willingly maintained belief in a theory he knew to be inconsistent with the views he was drafting and then publishing in the Essay? Anstey makes one general comment about Locke's interest in chymistry, and then presents four items to support his case that Locke was Helmontian. He then attempts to neutralise a comment by Locke that might be seen as critical of Helmontian theory. Let us consider his general claim first.

Regarding 'mercurial chymistry', Anstey says 'there is far more manuscript material pertaining to Locke's mercurialist chymistry than there is published material pertaining to

${ }^{23}$ Bodl. MS Locke f. 10, 5. 
corpuscularianism'. I am not quite sure what is being suggested here. First, it is not clear to me what Anstey means by the terms 'mercurialist chymistry' and 'corpuscularianism'. It is absolutely true that Locke took copious notes on chymical experimentation both at Oxford and afterward-but these practical reports are generally not statements of belief in Helmontian or chymical theory. Moreover, the contrast Anstey makes between this 'mercurialist chymistry' and 'corpuscularianism' seems to imply some sort of opposition. Is 'mercurial chymistry' a nonmechanical theory of agency? By 'corpuscularianism' does Anstey mean the 'austere mechanism' of the Essay? Anstey would help the reader by providing more detail in his description. If that is the case, is Anstey then trying to elide Locke's interest in the practice of chymistry with some non-mechanical theory of natural agency? Locke always retained a practical outlook, and was consistently interested in the practice of science, medicine, economics, politics and religion, even as his theoretical commitments changed over time. That Locke used the iron furnace from his luggage does not imply anything about how he believed it worked. Locke certainly did make numerous notes on his reading of chymical works, and on his own practical experimentation - but in itself that tells us little about what Locke believed about how all of this functioned. While at Oxford, Locke took scores of notes on the writings of the neo-Aristotelian Daniel Sennert, and apparently even structured one of his notebooks in accordance with Sennert's theoretical framework, ${ }^{24}$ but that does not make Locke a neo-Aristotelian.

Moreover, it is not clear that Anstey's claim is true as simple a matter of fact. The Essay contained numerous extended discussions of matters related to the internal constitution of objects - for example, those on primary and secondary qualities, substance, real and nominal essence, and so on-all of which were couched in terms of an austere mechanism, and all of which were published in multiple editions over several years. That was a lot of published words directly stating Locke's views about

\footnotetext{
${ }^{24}$ His notebook at the Biblioteca Marciana in Venice, shelfmark MS Lat. VII, 22.
} 
natural agency. Anstey concedes that Locke never 'publish[ed] anything on mercurial transmutational alchemy', ${ }^{25}$ but then goes on to say "That these ideas never appear in print is no indication that he did not subscribe to them". ${ }^{26}$ But if Locke did subscribe to these non-mechanical views, why did he never say so in print, given the abundant opportunity he had to do so? And if he was concerned about publication, why did he not express such views in The Elements of Natural Philosophy, if it was indeed written by Locke for the private use of Francis Masham? ${ }^{27}$ Or in correspondence with his close confidants? Or, indeed, to anyone on any occasion? By far and away the most likely explanation would seem to be that Locke, while interested in the practice of chymistry, did not subscribe to any non-mechanical theory of chymical agency - what Anstey appears to mean by 'mercurial transmutational alchemy'. That would plausibly explain why he never published anything. Is there some other explanation, silently presumed by Anstey's interpretation, why Locke kept his lifelong belief in this theory a secret?

Let us now turn to the four instances which Anstey believes show 'the nature, persistence and application of Locke's Helmontian conception of disease'. ${ }^{28}$

1. In 1679 a physician named William Jacob wrote to Locke mentioning the actions of 'ferments', the treatment of which Locke noted in his journal. ${ }^{29}$

2. In 1684, when discussing the treatment of colic, Locke used the phrase 'furente archaeo' i.e. 'the archeus being enraged' in his note

${ }^{25}$ Anstey, 'Further Reflections', 226.

${ }^{26}$ Anstey, 'Further Reflections', 226-27.

${ }^{27}$ Though see note 11 above.

${ }^{28}$ Anstey, 'Further Reflections', 227.

${ }^{29}$ Anstey, 'Further Reflections', 227, cf. William Jacob to Locke, c. 27 September 1680, Correspondence of John Locke (henceforth Corr.), Letter 576, vol. 2, 259-60; cf. Bodl. MS Locke f. 4, 174-75. 
on the subject. ${ }^{30}$

3. In 1688, 'Locke recorded some chymical receipts that interested him in his journal...chymical substances...integral to Helmontian medicine'.

4. In 1692, 'after Locke was appointed executor of Boyle's chymical papers he came into possession of a crucial document for understanding the development of Boyle's chymistry', concerning the preparation of the volatile salt of tartar, one of the substances 'integral to Helmontian medicine'. 32

This is all the evidence that Anstey presents for the assertion that Locke was an Helmontian throughout his career, and held fundamentally inconsistent views while drafting and publishing several editions of the Essay. 1, 2 and 4 are, at best, indications of interest in practical matters that may have had some Helmontian connection. They are by no means statements of Helmontian theory, and it is not even clear that Locke thought them particularly interesting because of any Helmontian associationchymical receipts for specific compounds would be interesting independent of their theoretical origins. So too prescriptions to treat particular ailments. And these are a small handful of notes among the hundreds that Locke made on such subjects throughout his career.

The reference to the archeus being enraged is certainly more suggestive - this does appear to be a direct reference to

30 Anstey, 'Further Reflections', 227-28, cf. Bodl. MS Locke f. 8, 214-15; transcribed in K. Dewhurst, John Locke: Physician and Philosopher (London, 1963), 262, and J. R. Milton, 'Locke, medicine and the mechanical philosophy', British Journal for the History of Philosophy 9 (2001): 221-43, at 239.

31 Anstey, 'Further Reflections', 228, cf. Bodl. MS Locke f. 9, 322, translated in Dewhurst, John Locke, 279-80.

32 Anstey, 'Further Reflections", 228-29, cf. Newman and Principe, Alchemy Tried in the Fire: Starkey, Boyle, and the Fate of Helmontian Chymistry (Chicago 2002), 218. The document is found at Bodl. MS Locke c. 29, 115r-118v. 
Helmontian theory. But Anstey seems unsure that this remark amounts to anything more than a manner of speaking. He says:

[T]he best way to approach this is to consider that given Locke's earlier formation as a Helmontian physician it was only natural for the trajectory of his conception of disease to continue to deploy Helmontian categories, rather than, say, Galenic ones. ${ }^{33}$

He then goes on to draw a parallel with the Cartesian vortex theory of the time. Locke was well acquainted with Descartes' theory of the vortex from his reading in Oxford. But Anstey does not appear to think that Locke subscribed to this theory:

Locke was becoming increasingly sceptical of Cartesian cosmological ideas throughout the $1680 \mathrm{~s}$, particularly after reviewing Newton's Principia in the Bibliothèque universelle in 1688. Indeed, the salient feature of Locke's review is the manner in which he reproduces Newton's arguments against Descartes' theory. ${ }^{34}$

But, Anstey notes, Locke later made reference to the vortex theory despite his scepticism:

We...find Locke...in 1695, speaking in terms of vortices when describing the progress of the young Francis Masham to William Molyneux: '[Francis] understands geography and chronology very well, and the Copernican system of our vortex.

Indeed, in his book, Anstey notes that in his published correspondence with Stillingfleet, Locke cited Newton's 'demolition of the vortex theory'. ${ }^{36}$ Drawing a parallel between

${ }^{33}$ Anstey, 'Further Reflections', 233.

34 Anstey, 'Further Reflections', 233, cf. John Locke, 'Philosophiae naturalis principia mathematica', Bibliothèque universelle et historique, 8 (1688): 436-50, esp. 440-43. For a detailed discussion see Anstey, JLNP, 91-97.

35 Anstey, 'Further Reflections', 233, cf. Locke to William Molyneux, 2 July 1695, Corr., Letter 1921, vol. 5, 406.

${ }^{36}$ Anstey, JLNP, 97, cf. Locke, Second Reply, 384. 
the vortex and the archeus, Anstey, perhaps unwittingly, appears to suggest that Locke did occasionally use terms of art from theories he no longer subscribed to as a useful form of shorthand. It seems perfectly reasonable to read Locke's use of the word 'archeus' in this manner, particularly when we recall that this is the only instance that Locke unambiguously used an Helmontian term of art in an unqualified manner at any point after 1667. This is the only piece of evidence that could be taken to suppose that Locke was an Helmontian throughout the 37 years he lived after he left Oxford. As far as I am aware, there are no others examples of an unqualified reference to Helmontian theory after 1667 anywhere in Locke's published or unpublished writings, in print, correspondence or manuscript. And this single piece of evidence is one which Anstey apparently believes, like Locke's use of the 'vortex', might have been little more than non-committal figure of speech, an intellectual hangover from his earlier engagement with the subject.

Let us then compare these few ambiguous items with the evidence that Locke did not subscribe to Helmontian theory after 1667. Anstey turns to what appears to be a reasonably forthright dismissal of Helmontian theory written almost as soon as Locke left Oxford, moved to London, and became acquainted with the physician Thomas Sydenham.

A paper titled 'Anatomia', in Locke's hand, and written in 1668 , presents a number of reasons why anatomy is likely to be no use to the physician. The precise origin and significance of the paper will be discussed below, but in a paper co-authored with Anstey, John Burrows demonstrated that Locke was almost certainly responsible for writing the work, ${ }^{37}$ and his later reiteration of its themes in the drafts of the Essay suggest that he was presenting views to which he firmly adhered. In this text, Locke sought to demonstrate that the anatomist's work is useless because we are never going to be able to penetrate into nature's causes. Indeed, this is the first example of what Anstey describes

${ }^{37}$ Anstey and Burrows, 'John Locke, Thomas Sydenham, and the authorship of two medical essays', in Electronic British Library Journal, 2009, article 3, 42 p. 
as Locke's 'corpuscular pessimism'. To illustrate his point, Locke undertakes an exercise of 'compare and contrast', equating the work of the anatomist with that of theorists both old and new. In doing this, he first wrote:

Ther is some thing therefor in the body \& the juices too curious \& fine for us to discerne which performes the offices in the severall parts governs the health \& produces the various motions in the body intus mens agitat molem, ${ }^{38} \&$ upon whose unconceivable alterations depends our health or sicknesse. hence a fright which causes some diseases as epilepsies hystericall fits, \& fatuity often cures others as agues \& as some report the gout its self \& tis probable in these cases twould puzzle the quickest sighted anatomist assisted too by the best microscope to finde any sensible alteration made either in the juices or solid parts of the body. Therefor this hidden $\delta \eta \mu$ iovpyò $\varsigma^{39}$ was soe much out of the reach of the senses yea \& apprehension of the ancients that not knowing what to conceive it they

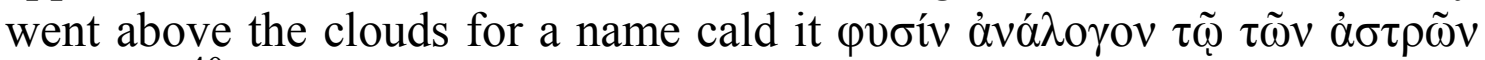

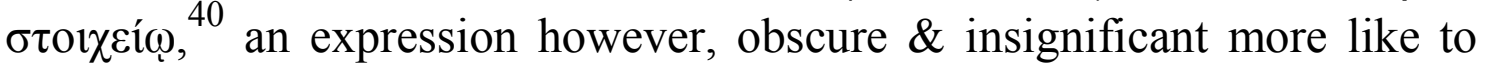
give us a usefull notion of the thing, then the anatomist to shew us this archeus as Helmont pleases to call it.

When revising the paper, however, he clearly felt that this description of Helmontian theory was not clear enough. So he deleted 'as Helmont pleases to call it', and replaced it in the margin with the phrase 'by which name Helmont has as clearely \& intelligibly explaind it to us as Aristotle by his description'.

Anstey is quite correct that 'the target here is the anatomist', but then continues by saying that this 'is not tantamount to a disdainful rejection of the notion of the archeus but of a rejection

38 'The mind moves the body from within', cf. Anstey, 'Further Reflections', 230, note 42 .

39 'Demiurge', see next note.

40 'A nature analogous to the element of the stars', both reference Aristotle's Generation of Animals Book II, Chapter III 736b 35ff. Daniel Sennert in his De Consensu \& Dissensu Galenicorum \& Peripateticorum cum Chymicis (Opera Omnia (Lyon, 1656), 177-284) quoted exactly this passage (200). Locke studied Sennert's work in general and this work in particular (cf. e.g., Bodl MS Locke f.18, 41 and 61); Sennert may well have been the source of this reference. 
of the claims of some anatomists'. ${ }^{41}$ It is not clear how Anstey reaches this conclusion. Locke is comparing the work of anatomists with that of ancient and modern theorists and asserting that all come up very short indeed. Locke is certainly not denying that, as Anstey puts it, there is an 'imperceptible power that governs health and produces motion in the body', but is stating that the anatomists' efforts at identifying and explaining are about as good as the theorists, that is to say no good at all. For the comparison to make any sense, the reader has to agree with the premise that the $\delta \eta \mu$ iov $\rho$ ò $\varsigma$ and archeus are identically useful descriptions of this 'imperceptible power', and that their utility is nil, because they are obscure, insignificant and unintelligible.

Indeed, Locke clearly thought that his first description of the archeus was not emphatic enough on this point, so went back to make it clear that he thought it was as useful as Aristotle's 'obscure and insignificant' description. If Anstey wants us to believe that Locke is somehow endorsing the 'archeus' here, then he must also be endorsing the Aristotelean $\delta \eta \mu$ iovpyò $\varsigma$ as an equally valid explanation of the 'imperceptible power', and it is clear that Locke rejected the Aristotelian theory throughout his career. Locke's remarks in 'Anatomia' are no less clear. The Helmontian archeus is about as good an explanation as Aristotle's $\delta \eta \mu$ iovpyòs, both of which are about as useful as the anatomist's efforts - and Locke was singularly unimpressed by all of them. Anstey's attempts to explain away Locke's dismissal of the archeus are unconvincing, because Locke obtrusively went out of his way to make clear just how unimpressed he was with the archeus as an explanation of the 'imperceptible power' Locke knew to be at work, but which he thought beyond our reach due to his 'corpuscular scepticism'.

But that was just one example from 'Anatomia' where Locke expressed a degree of scepticism about Helmontian theory. As the 'Review' of Anstey's book noted, there are three separate instances of Locke further asserting that we will never know whether 'ferments' are active agents because we cannot penetrate

${ }^{41}$ Anstey, 'Further Reflections', 231. 
into natural causes. ${ }^{42}$ And in both 'Anatomia' and 'De Arte Medica' from 1669, Locke suggests that chymistry will be of no use for a practising physician. ${ }^{43}$ Nor were these isolated incidents. In a 1692 letter to Thomas Molyneux, Locke suggested that the practice of medicine was too concerned with theory, and not enough with the observation of actual diseases and their cure, again bracketing chymistry with ancient medical practice and branding the language used in both as meaningless:

To which purpose I fear the Galenists four humours, or the chymists sal, sulphur, and mercury, or the late prevailing invention of acid and alcali, or whatever hereafter shall be substituted to these with new applause, will upon examination be found to be but so many learned empty sounds, with no precise determinate signification. ${ }^{44}$

And when he was writing a projected addition to his Essay, in a chapter On the Conduct of the Understanding, regarding medicine Locke asks

were it my Business to understand Physick, would not the safer and readier way be to consult Nature her self and inform my self in the History of Diseases and their Cures, than espousing the Principles of the Dogmatists, Methodists or Chymists ${ }^{45}$

These remarks are consistent with those from 'Anatomia' and 'De Arte Medica'. They are not the ringing endorsements of 'Helmontianism' or 'mercurialist chymistry' you might expect from a firm advocate of these theories, as Anstey apparently believes Locke was.

42 Walmsley, 'Review Article', 265-66, cf. NA PRO 30/24/47/2, ff. 31r-v, and Kenneth Dewhurst, Dr. Thomas Sydenham (1624-1689), His Life and Original Writings (London, 1966), 85-86; f. 32v and 87; ff. 33r-v and 88.

43 Walmsley, 'Review Article', 267, cf. NA PRO 30/24/47/2 ff. 37r-v and Dewhurst, Sydenham, 92-93; f. 52r and Dewhurst, Sydenham, 81.

${ }^{44}$ Locke to Thomas Molyneux, 20 January 1693, Letter 1593, Corr., vol. 4, 629.

${ }^{45}$ Locke, The Posthumous Works of Mr. John Locke (London 1706), 106. 
What, then, does Anstey have to say about these apparent counter-examples to his interpretation? How does he square these pointed, critical comments about Helmontian theory and 'chymistry' with his view of Locke as a life-long Helmontian and chymist? In short, in these 'Further Reflections', he does not address them at all and it is not clear how he could reconcile them with his preferred interpretation.

\section{\$2. Locke and Sydenham}

John Locke and Natural Philosophy was the culmination of Anstey's attempts to recast the understanding of the relationship between Locke and Sydenham. Rather than Locke being an acolyte of Sydenham's revolution in medical theory and practice, Anstey appears to hold that Sydenham was a quirky but peripheral quasi-traditional outsider whose work was transformed under Locke's guidance and whose position was elevated by Locke's promotion.

The 'Review' of John Locke and Natural Philosophy sought to show that this interpretation was questionable in a number of respects. There was no fundamental discontinuity between Sydenham's work prior to meeting Locke, and his work after. The Methodus Curandi Febres (1666) written before Sydenham met Locke, was in large part incorporated into its successor the Observationes Medicae (1676), written after the two men became acquainted, making the latter a continuation of the former. ${ }^{46}$ Anstey's account of the significance of case histories in Sydenham's work is directly contradicted by Sydenham himself in the preface to the Observationes. ${ }^{47}$ And Locke's expression of admiration for Sydenham's new medical methodology in

${ }^{46}$ Walmsley, 'Review Article', 274, cf. G. G. Meynell's introduction to his edition of the Methodus-Thomas Sydenham, Methodus Curandi Febres (Folkestone, 1987), vii-xx. A detailed collation of the two works is included in Greenhill's edition of Sydenham's works: Thomas Sydenham, Opera Omnia (London, 1844), ed. W. A. Greenhill, vol. I, xviii-xxi and 3-270 throughout.

47 Walmsley, 'Review Article', 273-74, cf. Thomas Sydenham, The Works of Thomas Sydenham, M.D., ed. R. G. Latham, (London, 1848), vol. 1, 24. 
correspondence with Thomas Molyneux firmly contradicts Anstey's interpretation. ${ }^{48}$ In these 'Further Reflections', Anstey does not comment on any of these points. Instead, he simply restates his position.

There is no doubt that Locke had enormous admiration for Sydenham, though in this he was in a small minority among his contemporaries. In my view, however, the evidence just does not support the thesis that Locke's views about the priority of experience over speculative hypotheses, his early critique of gross anatomy for therapeutics, his views concerning our lack of epistemic access to underlying causes of disease and his emphasis on the need for natural history, were derived from Sydenham. ${ }^{49}$

As evidence for this, Anstey cites his paper 'The Creation of the English Hippocrates'. ${ }^{50}$ This paper, published in 2011, does not take account of the points made in the 'Review', reiterated above. But it also omits new evidence that Anstey himself has provided.

As noted above, in 2009, John Burrows use statistical analysis to demonstrate that Locke composed 'Anatomia' and 'De Arte Medica'. 51 Further research by Anstey and Burrows shows these papers in a new light. In a 2013 article, Burrows again used statistical techniques to analyse two further medical manuscripts from the collaboration between the two men. ${ }^{52}$ These were a 'Dedicatory Epistle' and 'Preface' written in 1669 for a projected treatise on smallpox. ${ }^{53}$ Both of these papers were written in the

${ }^{48}$ Locke to Thomas Molyneux, 1 November 1692, Letter 1556, Corr., vol. 4, 563, and Locke to Thomas Molyneux, 20 January 1693, Letter 1593, Corr., vol. 4, 628-30, cf. Walmsley, 'Review Article', 278-80.

${ }^{49}$ Anstey, 'Further Reflections', 217.

50 Anstey, 'The Creation of the English Hippocrates', Medical History 55 (2011): $457-78$.

${ }^{51}$ Cf. note 37 above.

52 Anstey and Burrows, 'John Locke, Thomas Sydenham, and the 'Smallpox Manuscripts”, in English Manuscript Studies 18 (2013): 180-214.

${ }^{53}$ NA PRO 30/24/47/2 ff. 60-63 and 64-69 respectively. 
first person, from Sydenham's point of view, but both were in Locke's hand. The statistical analysis indicated that while Locke may have written the text down, the content of the text was composed by both men-some parts reflected Sydenham's writing style, some parts Locke's. The work was a hybrid of authorial styles, but written as if it were Sydenham's alone. Locke's role here was evidently that of a ghost-writer, helping to shape the prose style and argumentation of his colleague. Nor should this be a surprise, since around this time Locke acted as an amanuensis for Sydenham and also helped write expositions, apologetics and works for other associates. ${ }^{54}$

This confirmation of Locke's role as ghost-writer for Sydenham does, however, cast the authorship of 'Anatomia' and 'De Arte Medica' in a new light. If we know Locke ghost-wrote at least parts of the smallpox 'Dedicatory Epistle' and 'Preface', and Anstey has put his name to such a claim, it makes it much more likely that he was ghost-writing 'Anatomia' and 'De Arte Medica' for Sydenham as well-while Locke certainly wrote 'Anatomia' and 'De Arte Medica', he may only have done so at the request, and for the use, of Sydenham. Particularly when independent contemporary evidence suggests that Sydenham was writing works on these subjects at the time, ${ }^{55}$ and the interpolated first sentence at the beginning of 'Anatomia', indicating that it would be incorporated into a larger work, is in Sydenham's hand. In short, Anstey's claim that Locke independently authored 'Anatomia' and 'De Arte Medica' is weakened by the evidence that Anstey and Burrows provide to show that Locke acted as Sydenham's ghost-writer on the smallpox pieces.

54 The Essay concerning Toleration, the Fundamental Constitutions of Carolina and perhaps the entry on Carolina in Ogilby's America might all have been written by Locke for and at the request of others. Cf. Walmsley, 'Review Article', 281-82.

55 Around January 1669, John Ward recorded in his diary that 'Dr. Sydenham is writing a book wch will bring many physitians about his ears to decrie ye vsefulnes of natural philosophy and ye necessitie of knowledge in Anatomie in subordination to physic' (Wellcome Library MS 6173, p. 957 cf. Folger Library MS V.a. 295 f. 143v). 
To repeat: Anstey's 2011 article on 'The Creation of the English Hippocrates' takes no account of the points made in the 'Review Article', nor the new evidence of Locke's role as ghostwriter of the smallpox 'Dedicatory Epistle' and 'Preface'. Citing this article once again does not address these points. It is not clear how Anstey could reconcile this evidence with his interpretation.

Indeed, in the case of Sydenham, there are also significant gaps in the evidence that Anstey presents. Part of the reason Anstey believes Sydenham is unlikely to have played a significant role in Locke's career is his estrangement from the established medical community. Anstey advances two lines of argument support this conclusion. The first is that Sydenham had few wealthy patients - perhaps indicating, in Anstey's view, that Sydenham was something of a pariah and therefore inconsequential. The second is that Sydenham was not close to Boyle, and Boyle was unlikely to have valued Sydenham's work. The general conclusion to be drawn was that Locke was unlikely to have been impressed by such a peripheral figure, and if any influence and instruction flowed between the two men it was from Locke (a well-respected figure with friends in high places) to Sydenham (the outsider).

These arguments are non-sequiturs. Sydenham's professional standing has no bearing whatever on what Locke might have thought of him. A pariah to one man is a prophet to another, and Locke doubtless made up his own mind on the matter. Equally, whether Boyle valued or denigrated Sydenham's work has no particular bearing on Locke's view. Locke's reputation was not established by parroting the received views of his contemporaries and, as we shall see below, Locke did not always agree with Boyle. Equally important though, is evidence that counters the premises of both of these arguments. In the first place, as noted by G. G. Meynell, there is evidence that Sydenham had broadly mixed set of patients from a wide range of backgrounds - from aristocrats to the poor. ${ }^{56}$ Sydenham might have bemoaned his

${ }^{56}$ G. G. Meynell, Materials for a Bibliography of Thomas Sydenham (Folkestone, 1988), 24-25. 
difficulty in securing wealthy patients, but he clearly managed to do so. Equally, it is hard to think him completely cut off from the aristocracy when he lived next door to Katherine, Lady Ranelagh (Boyle's sister) in Pall Mall. Or that he lent substantial sums to aristocrats, as evidenced by the loan of $£ 200$ to his patient James Cecil, the third Earl of Salisbury, recorded at the time of the Earl's death. ${ }^{57}$ There might have been some good political reasons why Sydenham, a former officer in the Parliamentarian army, might have had some trouble making his way in Restoration Society, but he evidently managed to do so.

Secondly, with respect to Sydenham's relationship with Boyle, for some reason Anstey omits perhaps the single most telling piece of evidence. There are very few survivors from Boyle's library, but one of the handful of books still identifiable from his collection indicates a connection with Sydenham. In the Wellcome Library there is a copy of Gianfrancesco Riva di San Nazzaro's Tractatus de peste (Lyon, 1538). ${ }^{58}$ Boyle's signature appears in the middle of the title page. This page also bears Sydenham's name in the top margin on the right-hand side of the page. The book appears to have been a gift from one to the other - most likely from Boyle to Sydenham, as Boyle appears not to have signed the books that he kept in his library. ${ }^{59}$ This surely suggests a more than passing relationship between the two men. Locke, for instance, generally only gave his books away to very close associates. ${ }^{60}$ Why Anstey fails to mention this is not clearthe book is well known. A photo of its title page is reproduced in

${ }^{57}$ Meynell, Materials, 26-27, 79.

${ }^{58}$ Wellcome Library, shelfmark 5756/D.

${ }^{59}$ I. Aramov, M. Hunter and H. Yoshimoto, Boyle's Books: The Evidence of his Citations (London, 2010), xi.

${ }^{60}$ Most of the titles gifted from his library were given to Damaris and Francis Masham, Anthony Collins, Pierre Coste and Edward Clarke, cf. J. Harrison and P. Laslett, The Library of John Locke (Oxford, 1971), 44. 
a pair of articles about the men, and it is mentioned in a recent review of Boyle's reading. ${ }^{61}$

Regarding Locke's relationship to Sydenham, Anstey does not address evidence inconsistent with his interpretation, whether from questions posed in the 'Review Article' of his book, from his own analysis of Locke and Sydenham's writings, or elsewhere. A remark in his 'Further Reflections' may provide some indication why. Regarding his interpretation of Locke's medical interests, Anstey says:

Where I have diverged from the more traditional view of Locke's intellectual formation and the role of medicine therein, is the manner in which I have downplayed the influence of the London physician Thomas Sydenham on Locke's methodological views. ${ }^{62}$

Anstey sees himself as playing an active role- 'the manner in which I have downplayed the influence of London physician Thomas Sydenham'. Rather than letting the evidence guide his interpretation, he has avowedly sought to 'downplay' Sydenham's influence on Locke. This could be read as seeking to impose a predetermined pattern onto history, rather than constructing the history from the evidence.

\section{§3. Locke's 'deference' to Boyle}

Why would Anstey wish to 'downplay' the impact of Sydenham's thinking on Locke? One reason seems to be that Anstey wishes to (re-)establish Boyle as the primary inspiration for Locke's natural philosophical thinking, the 'Further Reflections' providing some examples of this theme in Anstey's work. Anstey represents Locke as Boyle's obedient pupil. For example, when stating that Locke was less than consistent in his

${ }^{61}$ J. F. Fulton, 'Boyle and Sydenham', in Journal of the History of Medicine 11 (1956): 351-52 and K. D. Keele, 'The Sydenham-Boyle Theory of Morbific Particles', in Medical History 18 (1974): 240-48, facing 240, cf. Aramov, Hunter and Yoshimoto, Boyle's Books, xi.

${ }^{62}$ Anstey, 'Further Reflections', 216-17. 
natural philosophical thinking, he cites Boyle as a reason: 'Locke's...deference to his mentors such as Boyle in chymistry... are also factors in play'. ${ }^{63}$ When describing Locke's supposedly inconsistent views in the Essay, Anstey says:

[Locke's] tentative endorsement of corpuscularianism in the Essay and his ongoing interest in mercurial chymistry, far from being inconsistent with Helmontianism, are exactly what one would expect of Locke, given his close association with Boyle. ${ }^{64}$

This form of argument also appeared in John Locke and Natural Philosophy. Boyle was working to Bacon's agenda in natural philosophy, Locke was too. If Boyle engaged in 'speculative natural philosophy', Locke did too. If Boyle was an alchemist and an Helmontian, then Locke was too. ${ }^{65}$

There's no doubt that Locke and Boyle had a long-standing and productive working relationship, and that Locke sought out and respected Boyle's views. But did Locke defer to Boyle? Indeed, did Locke defer to anyone intellectually? Locke took many notes from Boyle's books and made notes on chmyistry from the man himself. Locke adopted an argument for a distinction between Primary and Secondary Qualities that no doubt drew upon Boyle's earlier work on this subject (amongst others). But, in 'Morbus' Locke also went out of his way to criticise Boyle's explanations for certain natural phenomena. ${ }^{66}$ And in 'Respirationis Usus' Locke presented views on the properties of the air at odds with Boyle's. ${ }^{67}$ Locke doubtless valued Boyle's work, and agreed with him on numerous points.

${ }^{63}$ Anstey, 'Further Reflections', 232.

${ }^{64}$ Anstey, 'Further Reflections', 234.

${ }^{65}$ Anstey spells out these themes of his interpretation almost verbatim. Anstey, JLNP, 8-9.

${ }^{66}$ Walmsley, 'Morbus', 382-87.

${ }^{67}$ Walmsley, 'John Locke on Respiration', in Medical History 51 (2007): 453-76, at 471 and $475-76$. 
But Anstey will have to make a more compelling case that Locke deferred to Boyle on any subject if he wishes to build an interpretation of Locke's work upon such a claim. More broadly, an accurate account of Locke's thought can only be constructed through an independent assessment of Locke's work. Anstey started his career as a Boyle scholar and readers may suspect that he reads Locke's writings only as a series of footnotes to Boyle's work, rather than as the products of an independent thinker with his own perspective, interests and approach.

\section{$\$ 4$. Conclusion}

Anstey's "Further Reflections" are welcome, but several questions remain unanswered regarding his interpretation of Locke's natural philosophical career.

First, how can Anstey assert that Locke was a life-long Helmontian and an adherent of 'mercurialist transmutational alchemy', when the evidence for this assertion is extremely scanty and somewhat equivocal, and the evidence against it consistent, coherent, compelling and voluminous? In the 37 years after Locke left Oxford, Anstey can find only one unqualified use of an Helmontian phrase in the entirety of Locke's published and unpublished writings and correspondence, a use, moreover, which Anstey seems to intimate may well be nothing more than a contemporary turn of phrase. Compare this to the numerous examples where Locke denigrates Helmontian and 'chymical' theory from 'Anatomia' onwards, and his vigorous espousal of an austere mechanism in the drafts and published editions of the Essay. Compare also Locke's reaction when he noted that the austere mechanism of the Essay was inconsistent with Newton's discovery of universal gravitation. Locke did not assert that he was unconcerned because his mechanism accommodated all sorts of non-mechanical agency, or that he was undisturbed by inconsistency. Rather, he made changes to his argument to accommodate Newton's convincing demonstration of nonmechanical action. Locke remained interested in the practice of chymistry throughout his life, but there is no substantial evidence Locke believed in Helmontian theory or any other non- 
mechanical 'chymical' theory after he left Oxford. There is a great deal of evidence that he rejected all speculative theories, Helmontianism included, and advanced an austere mechanism, only modifying his views to accommodate Newton's work.

Second, many questions remain concerning Anstey's interpretation of the relationship between Locke and Sydenham. Anstey's claims about a change in Sydenham's works before and after he met Locke are undermined by the fact that the Methodus is largely incorporated into the Observationes. Anstey's claims about the importance of case histories in Sydenham's work after meeting Locke are refuted by Sydenham in the preface to the Observationes. Anstey's account of the relationship is inconsistent with Locke's own reports on the matter. Anstey appears to ignore his own evidence that Locke sometimes acted as a ghost-writer for Sydenham, making it much more likely that 'Anatomia' and 'De Arte Medica' are similarly hybrid works, similarly inspired by and written for Sydenham-a surmise supported by independent contemporary evidence. Anstey casts doubt on Sydenham's position in society and reputation in scientific circles, but does not address the evidence that Sydenham had a number of wealthy patients, and that a book passed between Sydenham and Boyle. Individually, any one of these points would weaken Anstey's arguments and undermine his interpretation. Collectively, they indicate significant issues with its foundations.

Third, Anstey appears to assume that Locke was little more than Boyle's assiduous acolyte, emulating his master on key natural philosophical issues. Anstey can certainly point to a close, productive and long-standing working and personal relationship between the two men. But he has provided no clear-cut evidence that Locke deferred to Boyle, that he always sought to emulate his colleague or that changes in Locke's natural philosophical views were invariably, or even typically, brought about directly and exclusively through Boyle's personal direction or the influence of his published works.

Finally, Anstey's work, as most recently expressed in these 'Further Reflections', raises broader question of how historical 
figures should be understood and interpretations of their work constructed. Is it right for the historian to 'downplay' this or that interpretation? Is it right for a historian to assert that one thinker deferred to another, without providing clear evidence that this is the case? Can a historian convincingly assert that 'the evidence just does not support' an interpretation while overlooking evidence inconsistent with their own views? How should historians develop, and then revise, their interpretations? ${ }^{68}$

London

${ }^{68}$ I am grateful to Professor J. R. Milton for several helpful corrections and suggestions, and to the editor for a number of judicious emendations, and the opportunity to present this article here. 